\title{
Suppression of RIZ in biologically unfavourable neuroblastomas
}

\author{
JANOS GELI $^{1}$, NIMROD KISS ${ }^{1}$, PER KOGNER $^{2}$ and CATHARINA LARSSON ${ }^{1}$ \\ Departments of ${ }^{1}$ Molecular Medicine and Surgery, ${ }^{2}$ Women and Child Health, Karolinska Institutet, Stockholm, Sweden
}

Received May 3, 2010; Accepted June 22, 2010

DOI: 10.3892/ijo_00000784

\begin{abstract}
Neuroblastoma is a paediatric solid tumor characterized by recurrent genomic abnormalities of prognostic importance. One of the most commonly observed abnormalities is deletion of the short arm of chromosome 1 and reduced expression of cancer related genes in this chromosomal arm. The long isoform of the retinoblastoma protein-interacting zink finger gene $(R I Z I)$ is a known tumor suppressor and a candidate neuroblastoma gene located at $1 \mathrm{p} 36.2$. The present study was undertaken to further assess the possible involvement of $R I Z$ in neuroblastoma development. Expression of $R I Z$ transcripts were quantified in a panel of neuroblastoma cell lines and tumors (33 neuroblastomas and 3 ganglioneuromas). Methylation status of promoter P1 driving RIZ1 expression was quantified by bisulfite Pyrosequencing. Only low mean levels of promoter methylation $(<10 \%)$ were observed in all samples. However, RIZ1 and RIZ1+2 mRNA were significantly under-expressed in biologically unfavourable tumors characterized by $1 \mathrm{p}$ loss $(\mathrm{p}<0.005)$ or $M Y C N$ amplification ( $\mathrm{p}<0.005)$. Suppression of RIZ1 is likely to contribute to the pathogenesis of biologically unfavourable neuroblastomas. In contrast to multiple other neoplasias, RIZ1 promoter methylation is not a common event in neuroblastoma.
\end{abstract}

\section{Introduction}

Neuroblastoma is a paediatric tumor derived from precursors of the sympathetic nervous system in the adrenal gland. The clinical presentation is highly variable ranging from spontaneous regression to rapid progression and fatal outcome. Tumor stage and clinical course is strongly associated with the presence or absence of certain molecular genetic aberrations (1). Molecular features of high-risk tumors include deletions of the short arm of chromosome 1, amplification of the MYCN locus and activating mutations of $A L K$ in chromosome 2 (2-4). Deletions of $1 \mathrm{p}$ occur in $>70 \%$ of high-risk tumors, and several groups have mapped smallest regions of loss to

Correspondence to: Dr Janos Geli, Department of Molecular Medicine and Surgery, KI, Karolinska University Hospital, CMM L8:01, SE-171 76 Stockholm, Sweden

E-mail: janos.geli@ki.se

Key words: neuroblastoma, RIZ, mRNA expression, promoter methylation 1p36 (5-11). The frequent losses of distal $1 \mathrm{p}$ in neuroblastomas suggest the presence of one or more neuroblastoma tumor suppressor gene loci in this region. While consistent mutations have not been demonstrated in candidate $1 \mathrm{p}$ genes, underexpression has been described for several cancer related genes located within as well as close to the region of loss. In addition to localized mutation, other means of allelic inactivation such as transcriptional silencing by promoter methylation or translational inhibition by micro-RNAs are anticipated (12-14).

The retinoblastoma interacting zinc finger protein gene (RIZ) is a known tumor suppressor located in chromosomal region $1 \mathrm{p} 36.2$, and a candidate neuroblastoma gene. The $R I Z$ locus generates two transcripts: RIZ1 from promoter P1 and RIZ2 from promoter $\mathrm{P} 2$. The corresponding proteins are identical at the C-terminal CR domain, but differ for the SET-domain that is present in the N-terminal PR-domain of the long RIZ1 isoform but not in the short RIZ2 isoform (15). The family of SET domain proteins have important functions in chromatin mediated transcriptional regulation, which in the case of RIZ1 involves methylation of histone $\mathrm{H} 3$ lysine 9 leading to transcriptional repression $(16,17)$. Another function of RIZ is as co-activator or co-repressor of nuclear hormone receptors (18).

Several studies in vitro and in vivo support that RIZ1 but not RIZ2 could function as a tumor suppressor in cancer development (19). Loss or reduced expression of RIZ1 has been reported in tumors of the breast, ovaries, colon, and liver as well as in pheochromocytoma (20-23). RIZ1 knock-out mice frequently develop diffuse large B cell lymphomas and other tumors (17). Reconstitution of RIZ1 expression in cancer cells induced cell cycle arrest, apoptosis and suppressed growth of tumor xenograft in immuncompromized mice $(21,23,24)$. Somatic RIZ mutations have also been reported, such as frameshift mutations at the $\mathrm{C}$ terminus in association with microsatellite instability $(21,25)$, and missense mutations at the N-terminal PR domain in various tumors and cancer cell lines (17). Finally, hypermethylation of promoter P1 has been reported in different types of tumors $(20,26-30)$.

The role of RIZ1 in neuroblastoma is not well understood. While RIZ1 and RIZ2 are highly expressed in normal neural tissues such as the adrenal medulla (31), under-expression of RIZ has been observed in aggressive neuroblastoma at genome-wide transcriptional profiling. Furthermore, promoter P1 methylation was found using qualitative approaches in one of the two studies where this was assessed $(32,33)$. To further characterize the involvement of RIZ in neuroblastoma we quantified mRNA expression levels and promoter P1 methylation density in a series of well characterized tumors and cell 
lines and correlated the findings to various clinico-pathological factors.

\section{Materials and methods}

Cell lines. Seven established neuroblastoma cell lines were studied: SK-N-DZ, SK-N-SH, SK-N-BE(2), SK-N-FI, SK-NAS, IMR-32, and SH-SY-5Y. Cells were grown under standard conditions (RPMI-1640 or Eagles's MEM for SH-SY-5Y, $10 \%$ fetal bovine serum, and $2 \mathrm{mmol} / \mathrm{l} \mathrm{L}$-glutamine) at $37^{\circ} \mathrm{C}$ in the presence of $5 \% \mathrm{CO}_{2}$.

Tumor samples. The study includes a total of 36 tumors from 36 children surgically treated for peripheral neuroblastic tumor (33 with neuroblastoma and 3 with ganglioneuroma) at the Karolinska University Hospital, Stockholm, Sweden (Tables I and II). All tissues were obtained with informed consent from patients or their legal guardians, as approved by the local ethics review board. After surgical removal tumor samples were dissected and snap-frozen in liquid nitrogen and stored at $-70^{\circ} \mathrm{C}$.

Detailed clinical and genetic information has been previously published for each case (34). In short, the cases represent all clinical and biological subsets of neuroblastoma, with a pattern of patient demography and tumor biology similar to that of the Swedish population. Diagnosis and staging followed the International Neuroblastoma Staging System (INSS) (35). MYCN amplification and 1p loss were determined as part of the standard characterization (36). In the case of pre-operative treatment this was given at the latest of 2 weeks before surgery, and radiation therapy was only given postoperatively. Four patients died of the disease (DOD) within $\leq 18$ months after diagnosis (cases 2, 3, 5 and 10), 2 patients died of surgical complications (cases 30 and 31) while 30 patients have survived for at least 17 months with a mean of 102 months. DNA from normal adrenal medulla was purchased from Clinomix (Watervliet, NY, USA) and used as non-tumorous reference.

RNA extraction and cDNA synthesis. Total RNA was extracted from frozen tumor samples using RNeasy RNA extraction kit (Qiagen). RNA yield was quantified by spectrophotometry, and RNA quality was assessed by demonstration of distinct $28 \mathrm{~S}$ and $18 S$ bands at denaturing gel electrophoresis (1\% agarose). cDNA was synthesized by reverse transcription from total RNA $(2 \mu \mathrm{g})$ in $100 \mu \mathrm{l}$ reactions using High-Capacity cDNA Archive kit (ABI) according to the recommendations of the manufacturer.

Real-time quantitative PCR ( $q R T$ - $P C R)$. Gene expression of $R I Z$ transcripts were quantified using TaqMan technology and an ABI PRISM 7700 Sequence Detection System. RIZ1 (RIZ-PR) and RIZ1+2 (RIZ-CR) were separately analysed using primers and probes that have been described in detail elsewhere (37). In addition two house-keeping genes were analysed in parallel using commercially available assays for $18 S$ and B2 microglobulin B2M (ABI assays on demand, assay Hs99999901_s1 and Hs00187842_m1). cDNA (65 ng) was amplified by PCR in TaqMan 2X Universal Master mix (final concentration $1 \mathrm{X}$ ) under the following conditions: $50^{\circ} \mathrm{C}$
Table I. Clinical and genetic details for the tumor cases studied.

\begin{tabular}{lccc}
\hline Parameter & Total & $\begin{array}{c}\text { Neuro- } \\
\text { blastoma }\end{array}$ & $\begin{array}{c}\text { Ganglio- } \\
\text { neuroma }\end{array}$ \\
\hline $\begin{array}{l}\text { Cases studied } \\
\text { Patients }\end{array}$ & 36 & 33 & 3 \\
$\quad$ Tumors & 36 & 33 & 3 \\
Sex & 16 & 15 & 1 \\
Female & 19 & 17 & 2 \\
Male & & & \\
Age at diagnosis & $0-145$ & $0-136$ & $59-145$ \\
Range (months) & & & - \\
High-risk therapy & 10 & 10 & 3 \\
$\quad$ Yes & 26 & 23 & \\
No & & &
\end{tabular}

Stage

$\begin{array}{lrrr}\text { Stage } 4 & 9 & 9 & - \\ \text { Stage } 1-3 & 21 & 21 & - \\ \text { Stage } 4 S & 3 & 3 & -\end{array}$

Loss in $1 p$

$\begin{array}{llll}\text { Loss } & 10 & 10 & - \\ \text { No loss } & 25 & 22 & 3\end{array}$

MYCN

$\begin{array}{llll}\text { Amplified } & 10 & 10 & - \\ \text { No amplification } & 26 & 23 & 3\end{array}$

Survival

\begin{tabular}{lrrr} 
DOD ( $\leq 18$ months $)$ & 4 & 4 & - \\
DOC & 2 & 2 & - \\
Alive ( $\geq 17$ months $)$ & 30 & 27 & 3 \\
\hline
\end{tabular}

DOD, dead of disease; DOC, dead of surgical complications.

for $2 \mathrm{~min}$; $95^{\circ} \mathrm{C}$ for $10 \mathrm{~min}$; and 40 cycles of $95^{\circ} \mathrm{C}$ for $15 \mathrm{sec}$ and $60^{\circ} \mathrm{C}$ for $1 \mathrm{~min}$. Each measurement was performed in duplicates.

A standard curve for relative expression quantification was generated by parallel amplification of serially diluted cDNA from human lymphocytes. Expression values for tumor samples and cell lines were subsequently related to the standard curve and then normalized to $18 S$ used as endogenous control. As an independent confirmation, expression values were also normalized to $B 2 M$ with highly similar results as compared to $18 S$ (data not shown). Furthermore a relative value of 1 was assigned to represent the average expression in tumors without $1 \mathrm{p}$ deletion.

DNA extraction and bisulfite treatment. High molecular weight DNA was extracted from tumor samples and cultured cells 
Table II. Results from RIZ promoter P1 methylation and gene-expression studies.

\begin{tabular}{|c|c|c|c|c|c|c|c|c|c|c|}
\hline \multirow[b]{2}{*}{$\begin{array}{l}\text { Case } \\
\text { no. }\end{array}$} & \multirow[b]{2}{*}{$\begin{array}{l}\text { Loss } \\
\text { of } 1 p\end{array}$} & \multirow[b]{2}{*}{$\begin{array}{c}\text { Other high-risk } \\
\text { features }\end{array}$} & \multirow[b]{2}{*}{$\begin{array}{l}\text { Tumor } \\
\text { type }\end{array}$} & \multicolumn{3}{|c|}{ P1 methylation $\%$} & \multicolumn{2}{|c|}{ RIZ1 mRNA/ } & \multicolumn{2}{|c|}{$R I Z 1+2 \mathrm{mRNA} /$} \\
\hline & & & & MetI & Min. & Max. & $18 S$ & $\begin{array}{c}\text { No } 1 \mathrm{p} \\
\text { loss }\end{array}$ & $18 S$ & $\begin{array}{c}\text { No } 1 \mathrm{p} \\
\text { loss }\end{array}$ \\
\hline \multicolumn{11}{|l|}{ Tumors } \\
\hline 2 & Loss & $M Y C N, 4, \mathrm{DOD}$ & NB & 5.7 & 3.2 & 11.4 & 1.3 & 0.2 & 5.6 & 0.05 \\
\hline 3 & Loss & $M Y C N, 4, \mathrm{DOD}$ & NB & 3.0 & 0.8 & 7.2 & 7.6 & 0.9 & 106.1 & 0.9 \\
\hline 4 & Loss & $M Y C N, 4$ & NB & 3.9 & 3.1 & 4.3 & 2.1 & 0.3 & 27.6 & 0.2 \\
\hline 5 & Loss & $M Y C N, 4, \mathrm{DOD}$ & NB & 5.0 & 4.1 & 6.3 & 1.8 & 0.2 & 27.2 & 0.2 \\
\hline 6 & Loss & $M Y C N$ & NB & 5.2 & 4.3 & 6.4 & 7.7 & 0.9 & 82.3 & 0.7 \\
\hline 7 & Loss & $M Y C N, 4$ & NB & - & - & - & 1.3 & 0.2 & 27.9 & 0.2 \\
\hline 8 & Loss & $M Y C N, 4$ & NB & 5.0 & 3.6 & 6.0 & 2.4 & 0.3 & 11.1 & 0.1 \\
\hline 9 & Loss & $M Y C N$ & NB & 2.1 & 1.7 & 3.6 & 3.6 & 0.4 & 25.6 & 0.2 \\
\hline 10 & No & $M Y C N, 4, \mathrm{DOD}$ & NB & 1.4 & 0.0 & 4.8 & 2.4 & 0.3 & 32.2 & 0.3 \\
\hline 11 & No & $M Y C N$ & NB & 1.4 & 0.9 & 1.6 & - & - & - & - \\
\hline 12 & No & No & NB & 5.2 & 2.2 & 13.9 & 12.4 & 1.5 & 300.0 & 2.5 \\
\hline 13 & No & No & NB & 6.1 & 2.8 & 12.8 & 8.8 & 1.1 & 120.3 & 1.0 \\
\hline 14 & No & No & NB & 8.9 & 5.2 & 11.2 & 13.6 & 1.6 & 66.7 & 0.5 \\
\hline 15 & No & No & NB & 2.9 & 2.2 & 3.3 & 4.0 & 0.5 & 87.3 & 0.7 \\
\hline 16 & No & No & NB & 2.9 & 0.0 & 5.9 & 8.1 & 1.0 & 150.4 & 1.2 \\
\hline 17 & No & No & NB & 2.8 & 1.2 & 9.8 & 12.7 & 1.5 & 127.4 & 1.0 \\
\hline 18 & No & No & NB & 2.6 & 1.1 & 6.1 & 9.7 & 1.2 & 92.0 & 0.8 \\
\hline 19 & No & No & Gang. & 1.3 & 0.0 & 4.4 & 8.2 & 1.0 & 84.0 & 0.7 \\
\hline 20 & No & No & Gang. & 2.3 & 1.2 & 4.2 & 3.4 & 0.4 & 44.0 & 0.4 \\
\hline 21 & No & No & NB & 2.6 & 1.5 & 4.2 & 9.4 & 1.1 & 95.1 & 0.8 \\
\hline 22 & No & 4 & NB & 3.6 & 2.4 & 7.6 & 11.2 & 1.4 & 142.7 & 1.2 \\
\hline 23 & No & No & NB & 6.6 & 4.4 & 15.0 & 3.1 & 0.4 & 178.0 & 1.5 \\
\hline 24 & No & No & NB & 4.2 & 0.0 & 21.5 & 5.0 & 0.6 & 72.0 & 0.6 \\
\hline 25 & No & No & NB & 2.0 & 0.0 & 3.9 & 11.7 & 1.4 & 125.9 & 1.0 \\
\hline 26 & No & No & NB & 6.0 & 1.7 & 17.1 & 10.5 & 1.3 & 95.2 & 0.8 \\
\hline 27 & No & No & Gang. & 4.5 & 2.7 & 7.5 & 1.6 & 0.2 & 82.1 & 0.7 \\
\hline 28 & Loss & No & NB & 4.3 & 3.2 & 6.0 & 6.3 & 0.8 & 40.6 & 0.3 \\
\hline 29 & No & No & NB & 1.0 & 0.0 & 2.2 & 11.4 & 1.4 & 213.7 & 1.8 \\
\hline 30 & No & No & NB & 7.0 & 3.2 & 18.3 & 14.8 & 1.8 & 289.8 & 2.4 \\
\hline 31 & - & No & NB & 2.3 & 0.0 & 4.5 & 3.0 & 0.4 & 40.0 & 0.3 \\
\hline 32 & No & No & NB & 0.8 & 0.7 & 1.0 & - & - & - & - \\
\hline 34 & No & No & NB & 1.2 & 0.9 & 1.5 & - & - & - & - \\
\hline 35 & No & 4 & NB & 0.7 & 0.5 & 0.9 & - & - & - & - \\
\hline 38 & No & No & NB & 1.4 & 0.0 & 2.6 & - & - & - & - \\
\hline 39 & No & No & NB & 6.2 & 3.9 & 9.5 & - & - & - & - \\
\hline 40 & Loss & No & NB & 7.2 & 9.7 & 12.0 & - & - & - & - \\
\hline \multicolumn{11}{|l|}{ Cell lines } \\
\hline IMR-32 & - & - & NB & - & - & - & 3.9 & 0.5 & 44.0 & 0.4 \\
\hline SH-SY-5Y & - & - & NB & - & - & - & 4.7 & 0.6 & 63.6 & 0.5 \\
\hline SK-N-AS & - & - & NB & 0.6 & 0.0 & 2.5 & 5.5 & 0.7 & 70.3 & 0.6 \\
\hline SK-N-BE(2) & - & - & NB & 1.1 & 0.8 & 1.6 & 5.6 & 0.7 & 79.5 & 0.7 \\
\hline SK-N-DZ & - & - & NB & - & - & - & 1.9 & 0.2 & 77.9 & 0.6 \\
\hline SK-N-F1 & - & - & NB & 3.0 & 2.1 & 3.8 & 5.6 & 0.7 & 130.2 & 1.1 \\
\hline SK-N-SH & - & - & NB & 5.4 & 3.3 & 10.6 & 2.5 & 0.3 & 62.6 & 0.5 \\
\hline
\end{tabular}

MYCN, amplification of $M Y C N$; 4, stage 4; DOD, dead of disease; NB, neuroblastoma; Gang, ganglioneuroma; mRNA expression in relation to $18 S$ as well as the mean value of tumors without $1 \mathrm{p}$ loss. 


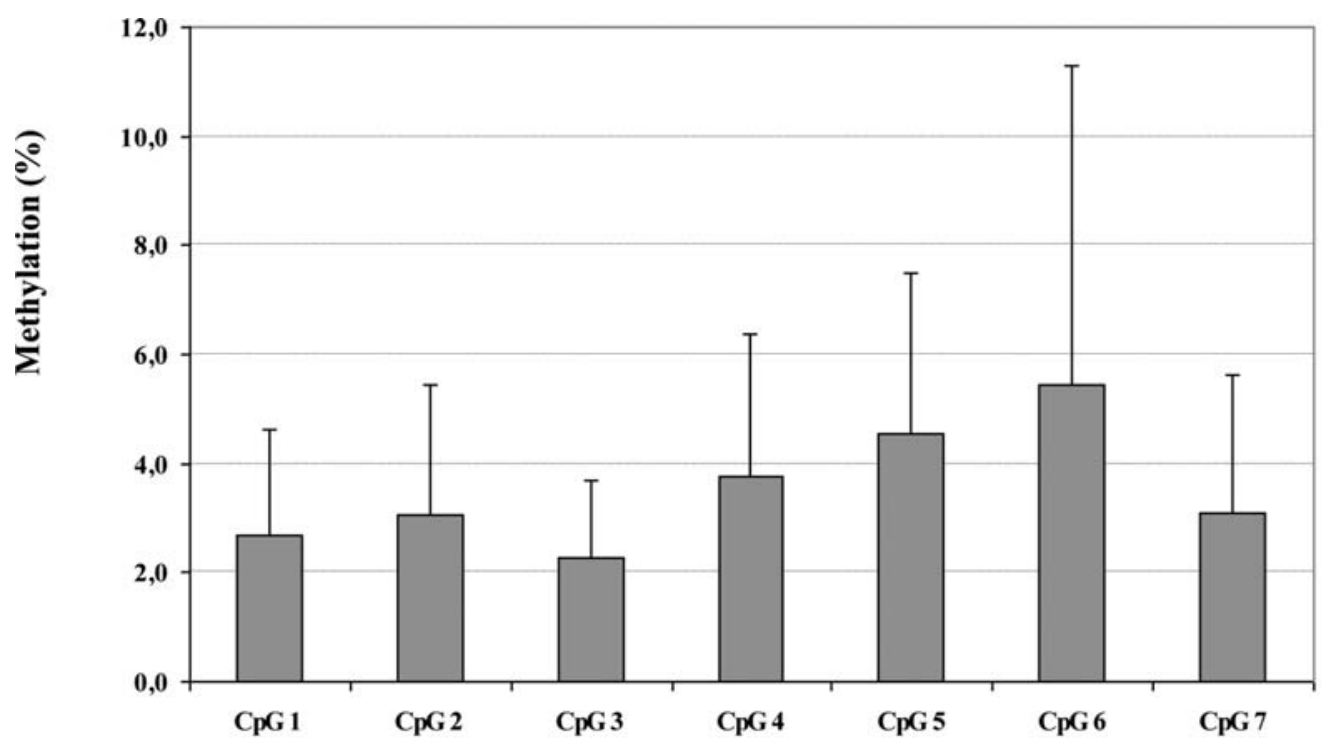

\section{Case 12}

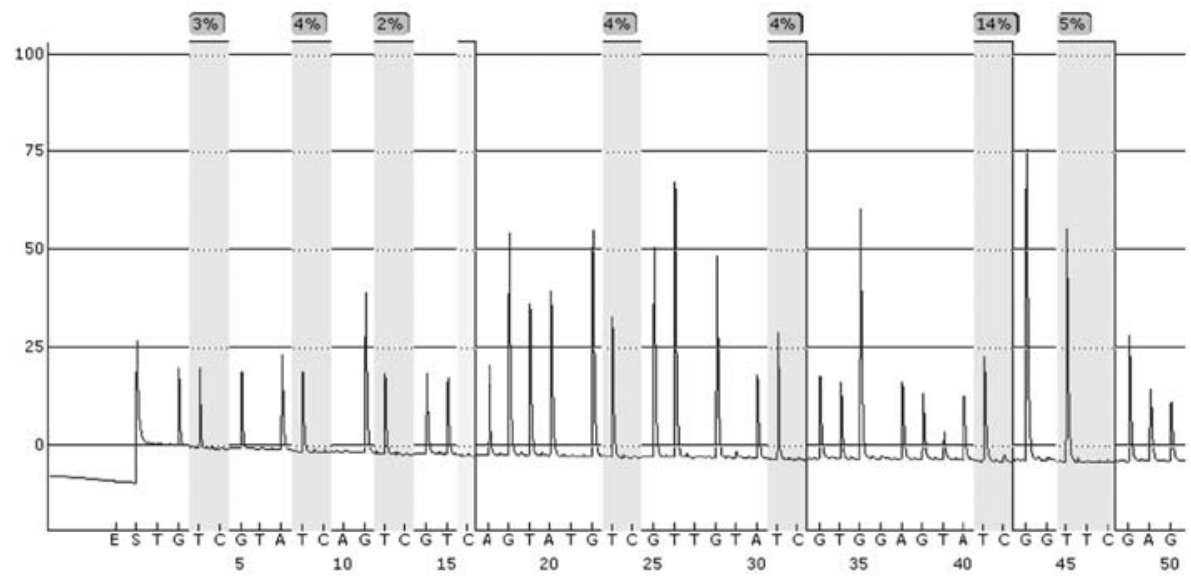

\section{Case 19}

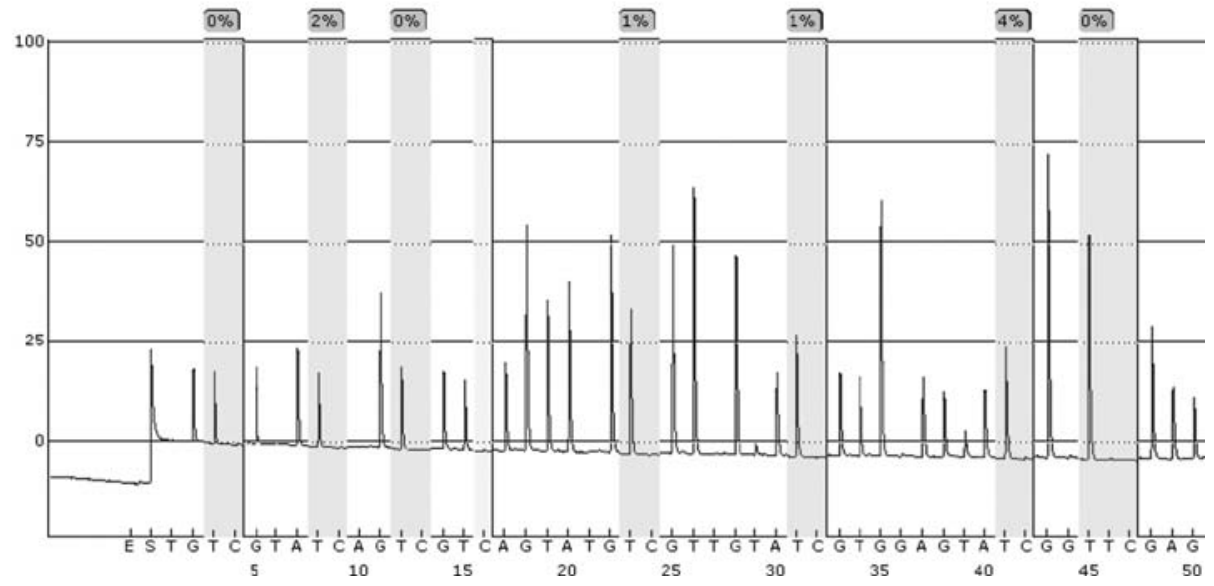

Figure 1. Quantification of RIZ promoter P1 methylation in neuroblastomas and ganglioneuromas. The diagram illustrates the mean methylation density at the $7 \mathrm{CpG}$ sites assayed in tumors 2-40. The results are exemplified in the Pyrograms below. Tumor no. 12 shows low MetI of 5.2\% with modestly increased methylation to $13.9 \%$ at $\mathrm{CpG}$ no. 6. Tumor no. 19 exhibit low MetI (1.3\%) with methylation in the range 0-4.4\% at individual CpGs.

using a standard method including proteinase $\mathrm{K}$ digestion, phenol-chloroform extraction and ethanol precipitation. DNA samples $(2 \mu \mathrm{g})$ were subsequently sodium bisulfite modified with the EZ DNA Methylation kit (Zymo Research Corp., Orange, USA) following the recommendations of the manufacturer. 
Pyrosequencing. Methylation density of the RIZ promoter $\mathrm{P} 1$ was quantified using a Pyrosequencing approach and the following primers: GGTTGGGTGGTGGTTATT and AAAC CTACCAAACTAAAAAACTCC. First, a 100-bp segment of the RIZ promoter P1 (Ensemble ID: ENSG00000116731) was amplified from bisulphite treated DNA (1.5 $\mu \mathrm{l})$ using Hot-start Taq polymerase, HotStar Taqs Master mix kit (Qiagen Ltd.) and the following conditions: $95^{\circ} \mathrm{C}$ for $15 \mathrm{~min}, 45$ cycles of $\left(95^{\circ} \mathrm{C}\right.$ for $20 \mathrm{sec}, 53^{\circ} \mathrm{C}$ for $20 \mathrm{sec}$ and $72^{\circ} \mathrm{C}$ for $20 \mathrm{sec}$ ), and $72^{\circ} \mathrm{C}$ for $10 \mathrm{~min}$. After verification at $3 \%$ agarose gel electrophoresis, PCR products were subjected to Pyrosequencing using the PSQ ${ }^{\mathrm{TM}} \mathrm{HS} 96$ system (Qiagen Ltd.), PyroGold reagents (Qiagen) and the sequencing primer GGGTGGT GGTTATTGG. The resulting Pyrograms were evaluated using Pyro Q-CpG software (Biotage AB), and the C:T peak ratios at the 7 individual $\mathrm{CpG}$ sites reflect the proportion of methylated to non-methylated alleles. A non- $\mathrm{CpG} \mathrm{C}$ within the assayed sequences served as internal control for efficiency of bisuphite conversion. In all runs SssI treated human lymphocyte DNA was included as positive control for hypermethylation. For each sample a methylation index (MetI) was calculated as the mean level of methylation recorded at the $7 \mathrm{CpGs}$ examined in $R I Z$ promoter $\mathrm{P} 1$, and in addition the methylation level at each individual $\mathrm{CpG}$ site was considered.

Statistical analyses. Statistical calculations were done using STATISTICA version 7 (Statsoft, Inc., Tulsa, OK, USA), and p-values $\leq 0.05$ were regarded as statistically significant. Differences in RIZI (RIZ-PR) and RIZI+2 (RIZ-CR) expression were compared by Mann-Whitney $U$ test with regard to MYCN amplification status, loss in chromosomal arm 1p, stage 4 vs. non-stage 4 tumors, high-risk vs. low-risk status, female vs. male sex, and ganglioneuromas vs. neuroblastomas. To estimate whether there was a difference between the extent of expressional reduction of $R I Z 1$ and $R I Z 1+2$ in $M Y C N$ amplified tumors the mean expression values for $R I Z 1$ and $R I Z 1+2$ for $M Y C N$ non-amplified tumors were divided by the respective expression values observed in each individual tumor with $M Y C N$ amplification. These values would then reflect the fold difference, i.e., the level of reduction of $R I Z 1$ and $R I Z 1+2$ expression compared to the means of $R I Z 1$ and $R I Z 1+2$ expression in the $M Y C N$ non-amplified group. Mann-Whitney $\mathrm{U}$ test was then used to compare if there was a difference between the degree of reduction for RIZI and RIZ1+2 in MYCN amplified tumors. Similar analyses were also used to compare tumors with vs. without $1 p$ loss. Kruskal-Wallis analysis was used to evaluate differences in $R I Z 1 / R I Z 1+2$ expressions between tumors of different clinical stages. Spearman Rank Order Correlations were used to assess correlation between RIZI/ $R I Z 1+2$ expression and age at presentation.

\section{Results}

Hypermethylation of RIZ promoter $P 1$ is a rare event in neuroblastoma. Methylation indices MetI representing mean level of methylation for the $7 \mathrm{CpG}$ sites investigated ranged from 0.7 to $8.9 \%$ (Table II; exemplified in Fig. 1). An arbitrary cut-off at $10 \%$ MetI was applied for hypermethylation, which is in general agreement with most studies applying Pyrosequencing for methylation quantification. In addition, a normal
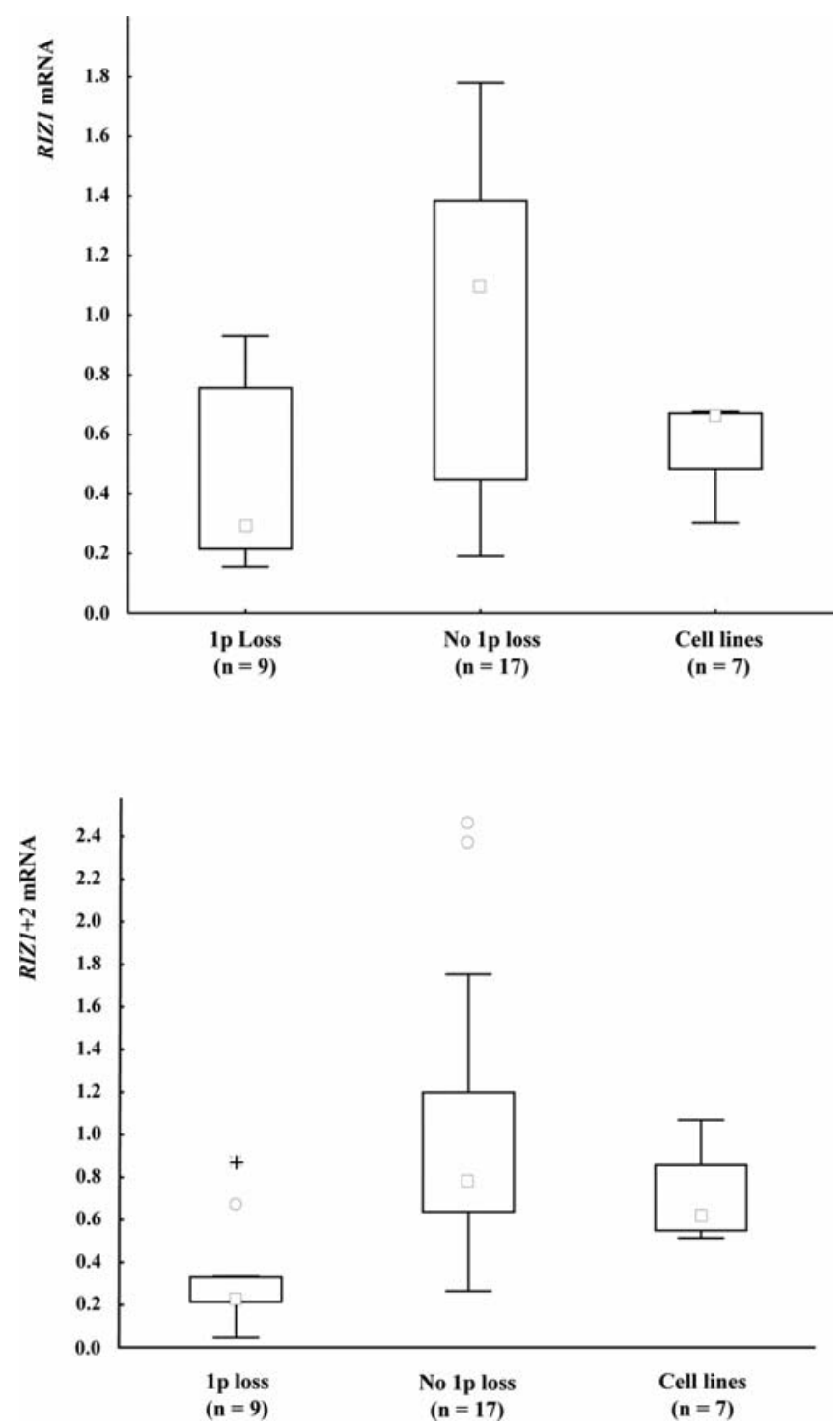

Figure 2. Boxplots illustrating relative expression of RIZ1 (top) and RIZ1+2 (bottom) in neuroblastoma tumors and cell lines. Presented expression values were normalized to $18 \mathrm{~S}$ and subsequently related to the arbitrary mean of 1.0 assigned to neuroblastomas without $1 \mathrm{p}$ loss. Significantly reduced expression is observed in biologically unfavourable tumors with $1 \mathrm{p}$ loss as compared to those without $1 \mathrm{p}$ loss.

adrenal medulla showed MetI at 2.6\% (range 0.8-5.7\%). Nine neuroblastomas and one cell line exhibited increased methylation at one or more individual $\mathrm{CpG}$ sites although the MetI was still $<10 \%$. Methylation levels $>10 \%$ were predominantly recorded at $\mathrm{CpG} 6$ (Fig. 1). The remaining tumors and cell lines showed low methylation $<10 \%$ at all individual sites examined.

Suppression of RIZ1 and RIZ1+2 expressions in aggressive neuroblastoma. Expression of RIZ transcripts were measured for $R I Z 1$ and $R I Z 1+2$ separately by qRT-PCR in tumors and cell lines (Table II). Comparison of $R I Z 1$ and $R I Z 1+2$ expression with clinical and genomic tumor characteristics revealed several significant associations suggesting suppressed expression in high-risk disease. Significantly lower levels of $R I Z 1$ as well as $R I Z 1+2$ expressions were detected among 


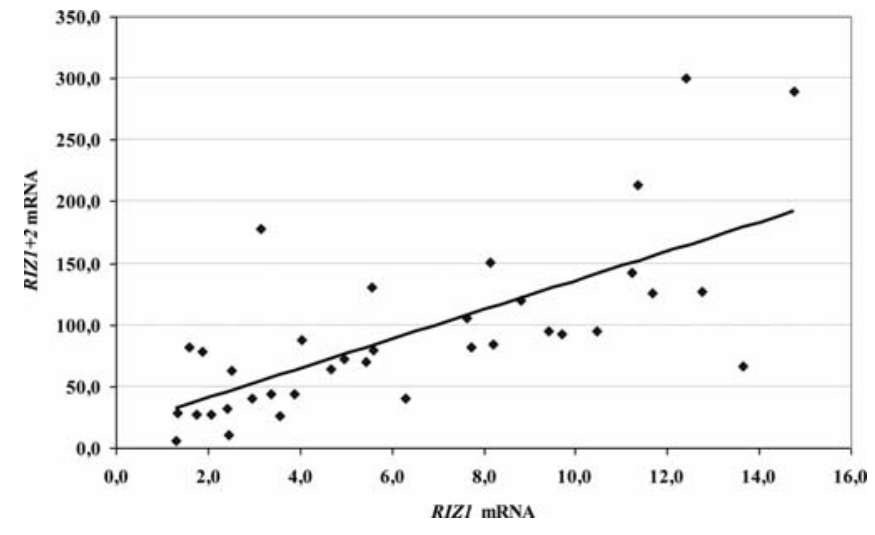

Figure 3. Comparison of RIZ1 and RIZ1+2 mRNA expression levels in tumors and cell lines.

neuroblastomas with $1 \mathrm{p}$ loss as compared to those without this abnormality $(\mathrm{p}<0.005$; Mann-Whitney U test). Similarly, significantly lower levels of $R I Z 1$ and $R I Z 1+2$ were found in tumors with $M Y C N$ amplification compared to those without amplification, and in neuroblastomas classified as INSS stage 4 compared to tumors of lower stages ( $<<0.005$; Mann-Whitney $\mathrm{U}$ test). No significant difference was observed in the extent of reduction for $R I Z 1$ as compared to $R I Z 1+2$ in tumors with 1p loss or $M Y C N$ amplification. No difference was demonstrated between ganglioneuromas and neuroblastomas with regard to $R I Z 1$ and $R I Z 1+2$ expressions. Lower $R I Z 1$ expression was observed in tumors from patients with a later age at presentation $(\mathrm{p}<0.05$; Spearman Rank Order Correlations). There was also a tendency towards higher $R I Z 1$ and $R I Z 1+2$ expressions in stage $4 \mathrm{~S}$ tumors (cases 12, 18 and 29) compared to low stage (stages 1 and 2) cases. However, this did not reach the level of statistical significance.

Overall the 7 neuroblastoma cell lines examined showed low levels of $R I Z 1$ and $R I Z I+2$ expressions. To simplify comparisons between groups of samples, the expression levels were related to an arbitrary mean of 1.0 assigned to the group of neuroblastomas without $1 \mathrm{p}$ loss (Table II). As illustrated in Fig. 2 this revealed relatively high expression levels in tumors without $1 \mathrm{p}$ loss, and low levels in tumors with $1 \mathrm{p}$ loss as well as in neuroblastoma cell lines.

\section{Discussion}

Here we report substantially reduced RIZ1 and RIZ2 mRNA levels in $1 \mathrm{p}$ deleted neuroblastomas, a subset which is highly associated with unfavourable prognosis (2). At an average, a 2-fold RIZ1 mRNA reduction was seen in 1p deleted cases, compared to the mean expression in tumors without $1 \mathrm{p}$ loss. $R I Z 1+2$ also showed a similar relative decrease, suggesting that not only RIZ1 but also RIZ2 expression is suppressed. Two 1p deleted cases showed no major decrease in $R I Z$ expression (cases 3 and 6).

Low levels of RIZ1 expression were demonstrated by He et al in a panel of 7 neuroblastomas and 7 cell lines. Interestingly the two cases showing low RIZ1 levels were classified as stages 2 and 4S (23) - a feature associated with favourable outcome. In contrast, we found reduced RIZI expression in a subset of the cases characterized by high-stage and biologically unfavourable behaviour. A more recent study that compared global gene expression pattern differences between $1 \mathrm{p}$ deleted and non-deleted neuroblastomas, also noted differential expression of RIZ (38). However, no data were presented concerning the degree of expressional reduction and the particular $R I Z$ transcript involved. Our data provide quantitative corroboration of the above reports on RIZ1 suppression, on an independent well characterized series. Furthermore, our mRNA expression results provide indication that levels of both RIZ transcripts are reduced (Table II and Fig. 3). This contrasts the scenario seen in most other tumor types, where usually only RIZ1 is reduced $(23,24)$ and in some neoplasias RIZ2 may even show relative overexpression (37). The preferential expression of RIZ in fetal and adult neuroendocrine tissues, as well as expressional suppression in cancer, indicate a role for these molecules in both normal development and pathogenic processes of neuroendocrine tissues (31). To gain insight into the significance of this observation, further investigation of the role of RIZ2 in normal neuroendocrine development and carcinogenesis is required.

A number of other candidate neuroblastoma tumor suppressor genes at 1p36.2-3 show expressional reduction in $1 \mathrm{p}$ deleted neuroblastomas (38-42). Therefore it is likely that transcriptional alteration in multiple genes cooperate in the pathogenesis of neuroblastomas. Several lines of evidence suggest a tumor suppressor role for RIZ1 (19). One of the known cellular functions of RIZ1 is methylation of the lysine 9 residue on Histone H3, which is a chromatin modification associated with heterochromatinization and transcriptional repression $(16,17)$. It is thus possible that reduced $R I Z 1$ expression may lead to the activation of genes favouring cell growth.

Various mechanisms could potentially lead to suppressed mRNA expression, including structural mutations, deletions, epigenetic modifications and other diverse regulatory mechanisms at the transcriptional or post-transcriptional levels. Epigenetic inactivation by promoter methylation has been implicated as a common mechanism underlying RIZ1 silencing $(20,26-30)$. In view of these findings, and our present observation of frequent suppression of RIZ1 mRNA expression we have quantitatively assessed $R I Z 1$ promoter methylation in the tumor panel and four neuroblastoma cell lines. None of the tumors or cell lines analyzed showed MetI at $>10 \%$ in the $R I Z 1$ promoter.

Previously, a few studies have undertaken to analyze RIZ1 promoter methylation in neuroblastoma $(33,43)$. All of these reports utilized a non-quantitative method, methylation specific PCR (MSP), and the results reveal some discrepancies. Alaminos et al observed 26\% RIZ1 methylation frequency in a series of 45 neuroblastomas (32). In contrast Hoebeeck et al found no methylation in a panel of 42 tumors (33). Divergent findings were also seen in neuroblastoma cell lines. Hoebeck et al and Alaminos et al observed RIZ1 methylation in 9 out of 33 and 5 out of 10 neuroblastoma cell lines, respectively $(32,33)$. In contrast Van Noesel et al found no methylation in 22 neuroblastoma cell lines (43). Furthermore, three of the cell lines reported to be methylated by Hoebeck and colleagues did not show methylation in the work by van Noesel et al $(33,43)$. These discrepancies could 
potentially arise due to differences in assay sensitivity and different CpGs assessed. MSP is generally a highly sensitive method (44). This feature together with the fact that the technique is non-quantitative may result in classifying a tumor as methylated on the basis of a minor proportion of methylated template. Besides technical restraints, conflicting methylation data in cell lines may also possibly arise due to epigenetic plasticity associated with propagation of cells in culture (45). Here we have quantified methylation density of the RIZ1 promoter for several consecutive $\mathrm{CpGs}$ by Pyrosequencing. Our findings indicate that RIZ1 promoter hypermethylation is typically present only in a small proportion of tumor cells $(<10 \%)$. None of the 33 neuroblastomas showed high methylation levels, suggesting that RIZ1 P1 methylation is unlikely to contribute to tumor progression.

Taken together, our data provide further evidence that $R I Z$ is a target tumor suppressor gene in $1 \mathrm{p} 36.2$ in unfavourable neuroblastomas. Although RIZ1 promoter methylation frequently occurs in other neoplasias, it is uncommon in neuroblastomas. It is highly possible that a more aggressive behaviour and poor prognosis for $1 \mathrm{p}$ deleted neuroblastomas is a composite result of expressional suppression of several tumor suppressor genes in this chromosomal region, of which, RIZI represents one attractive target.

\section{Acknowledgements}

The authors would like to thank Lotta Elfman for expert tumor sample handling. This study was supported by grants from The Swedish Cancer Foundation, The Swedish Research Council and The Damman's Foundation.

\section{References}

1. Maris JM, Hogarty MD, Bagatell R and Cohn SL: Neuroblastoma. Lancet 369: 2106-2120, 2007.

2. Attiyeh EF, London WB, Mosse YP, Wang Q, Winter C, Khazi D, McGrady PW, Seeger RC, Look AT, Shimada H, Brodeur GM, Cohn SL, Matthay KK and Maris JM: Chromosome 1p and 11q deletions and outcome in neuroblastoma. N Engl J Med 353: 2243-2253, 2005.

3. Brodeur GM, Green AA, Hayes FA, Williams KJ, Williams DL and Tsiatis AA: Cytogenetic features of human neuroblastomas and cell lines. Cancer Res 41: 4678-4686, 1981.

4. Mosse YP, Laudenslager M, Longo L, Cole KA, Wood A, Attiyeh EF, Laquaglia MJ, Sennett R, Lynch JE, Perri P, Laureys G, Speleman F, Kim C, Hou C, Hakonarson H, Torkamani A, Schork NJ, Brodeur GM, Tonini GP, Rappaport E, Devoto M and Maris JM: Identification of ALK as a major familial neuroblastoma predisposition gene. Nature 455: 930-935, 2008.

5. Bauer A, Savelyeva L, Claas A, Praml C, Berthold F and Schwab M: Smallest region of overlapping deletion in 1p36 in human neuroblastoma: a $1 \mathrm{Mbp}$ cosmid and PAC contig. Genes Chromosomes Cancer 31: 228-239, 2001.

6. Caron H, Spieker N, Godfried M, Veenstra M, van Sluis P, De Kraker J, Voute P and Versteeg R: Chromosome bands 1p35-36 contain two distinct neuroblastoma tumor suppressor loci, one of which is imprinted. Genes Chromosomes Cancer 30: $168-174,2001$

7. Cheng NC, van Roy N, Chan A, Beitsma M, Westerveld A, Speleman F and Versteeg R: Deletion mapping in neuroblastoma cell lines suggests two distinct tumor suppressor genes in the 1p35-36 region, only one of which is associated with $\mathrm{N}$-myc amplification. Oncogene 10: 291-297, 1995.

8. Martinsson T, Sjoberg RM, Hallstensson K, Nordling M, Hedborg $\mathrm{F}$ and Kogner P: Delimitation of a critical tumour suppressor region at distal $1 \mathrm{p}$ in neuroblastoma tumours. Eur J Cancer 33: 1997-2001, 1997
9. Schleiermacher G, Peter M, Michon J, Hugot JP, Vielh P, Zucker JM, Magdelenat H, Thomas G and Delattre O: Two distinct deleted regions on the short arm of chromosome 1 in neuroblastoma. Genes Chromosomes Cancer 10: 275-281, 1994.

10. Takeda O, Homma C, Maseki N, Sakurai M, Kanda N, Schwab M, Nakamura Y and Kaneko Y: There may be two tumor suppressor genes on chromosome arm $1 \mathrm{p}$ closely associated with biologically distinct subtypes of neuroblastoma. Genes Chromosomes Cancer 10: 30-39, 1994.

11. White PS, Thompson PM, Gotoh T, Okawa ER, Igarashi J, Kok M, Winter C, Gregory SG, Hogarty MD, Maris JM and Brodeur GM: Definition and characterization of a region of 1 p36.3 consistently deleted in neuroblastoma. Oncogene 24 : 2684-2694, 2005

12. Banelli B, Di Vinci A, Gelvi I, Casciano I, Allemanni G, Bonassi S and Romani M: DNA methylation in neuroblastic tumors. Cancer Lett 228: 37-41, 2005.

13. Cole KA, Attiyeh EF, Mosse YP, Laquaglia MJ, Diskin SJ, Brodeur GM and Maris JM: A functional screen identifies miR-34a as a candidate neuroblastoma tumor suppressor gene. Mol Cancer Res 6: 735-742, 2008.

14. Schulte JH, Horn S, Schlierf S, Schramm A, Heukamp LC, Christiansen H, Buettner R, Berwanger B and Eggert A: MicroRNAs in the pathogenesis of neuroblastoma. Cancer Lett 274: 10-15, 2009

15. Huang S: The retinoblastoma protein-interacting zinc finger gene RIZ in 1p36-linked cancers. Front Biosci 4: D528-D532, 1999.

16. Kim KC, Geng L and Huang S: Inactivation of a histone methyltransferase by mutations in human cancers. Cancer Res 63: 7619-7623, 2003

17. Steele-Perkins G, Fang W, Yang XH, van Gele M, Carling T, Gu J, Buyse IM, Fletcher JA, Liu J, Bronson R, Chadwick RB, De la Chapelle A, Zhang X, Speleman F and Huang S: Tumor formation and inactivation of RIZ1, an Rb-binding member of a nuclear protein-methyltransferase superfamily. Genes Dev 15: 2250-2262, 2001

18. Abbondanza C, Medici N, Nigro V, Rossi V, Gallo L, Piluso G, Belsito A, Roscigno A, Bontempo P, Puca AA, Molinari AM, Moncharmont B and Puca GA: The retinoblastoma-interacting zinc-finger protein RIZ is a downstream effector of estrogen action. Proc Natl Acad Sci USA 97: 3130-3135, 2000.

19. Canote R, Du Y, Carling T, Tian F, Peng Z and Huang S: The tumor suppressor gene RIZ in cancer gene therapy (review). Oncol Rep 9: 57-60, 2002.

20. Akahira J, Suzuki F, Suzuki T, Miura I, Kamogawa N, Miki Y, Ito K, Yaegashi N and Sasano H: Decreased expression of RIZ1 and its clinicopathological significance in epithelial ovarian carcinoma: correlation with epigenetic inactivation by aberrant DNA methylation. Pathol Int 57: 725-733, 2007.

21. Chadwick RB, Jiang GL, Bennington GA, Yuan B, Johnson CK, Stevens MW, Niemann TH, Peltomaki P, Huang S and De la Chapelle A: Candidate tumor suppressor RIZ is frequently involved in colorectal carcinogenesis. Proc Natl Acad Sci USA 97: 2662-2667, 2000.

22. Geli J, Nord B, Frisk T, Edstrom Elder E, Ekstrom TJ, Carling T, Backdahl $\mathrm{M}$ and Larsson C: Deletions and altered expression of the RIZ1 tumour suppressor gene in 1p36 in pheochromocytomas and abdominal paragangliomas. Int J Oncol 26: 1385-1391, 2005.

23. He L, Yu JX, Liu L, Buyse IM, Wang MS, Yang QC, Nakagawara A, Brodeur GM, Shi YE and Huang S: RIZ1, but not the alternative RIZ2 product of the same gene, is underexpressed in breast cancer, and forced RIZ1 expression causes G2-M cell cycle arrest and/or apoptosis. Cancer Res 58: 4238-4244, 1998.

24. Jiang G, Liu L, Buyse IM, Simon D and Huang S: Decreased RIZ1 expression but not RIZ2 in hepatoma and suppression of hepatoma tumorigenicity by RIZ1. Int J Cancer 83: 541-546, 1999.

25. Sakurada K, Furukawa T, Kato Y, Kayama T, Huang S and Horii A: RIZ, the retinoblastoma protein interacting zinc finger gene, is mutated in genetically unstable cancers of the pancreas, stomach, and colorectum. Genes Chromosomes Cancer 30: 207-211, 2001

26. Carling T, Du Y, Fang W, Correa P and Huang S: Intragenic allelic loss and promoter hypermethylation of the RIZ1 tumor suppressor gene in parathyroid tumors and pheochromocytomas. Surgery 134: 932-939, 2003 
27. Hasegawa Y, Matsubara A, Teishima J, Seki M, Mita K, Usui T, Oue N and Yasui W: DNA methylation of the RIZ1 gene is associated with nuclear accumulation of p53 in prostate cancer. Cancer Sci 98: 32-36, 2007.

28. Lal G, Padmanabha L, Smith BJ, Nicholson RM, Howe JR O'Dorisio MS and Domann FE: RIZ1 is epigenetically inactivated by promoter hypermethylation in thyroid carcinoma. Cancer 107: 2752-2759, 2006

29. Oshimo Y, Oue N, Mitani Y, Nakayama H, Kitadai Y, Yoshida K, Chayama $\mathrm{K}$ and Yasui W: Frequent epigenetic inactivation of RIZ1 by promoter hypermethylation in human gastric carcinoma. Int J Cancer 110: 212-218, 2004.

30. Piao GH, Piao WH, He Y, Zhang HH, Wang GQ and Piao Z Hyper-methylation of RIZ1 tumor suppressor gene is involved in the early tumorigenesis of hepatocellular carcinoma. Histol Histopathol 23: 1171-1175, 2008.

31. Buyse IM, Shao G and Huang S: The retinoblastoma protein binds to RIZ, a zinc-finger protein that shares an epitope with the adenovirus E1A protein. Proc Natl Acad Sci USA 92: 4467-4471, 1995

32. Alaminos M, Davalos V, Cheung NK, Gerald WL and Esteller M: Clustering of gene hypermethylation associated with clinical risk groups in neuroblastoma. J Natl Cancer Inst 96: 1208-1219, 2004 .

33. Hoebeeck J, Michels E, Pattyn F, Combaret V, Vermeulen J Yigit N, Hoyoux C, Laureys G, De Paepe A, Speleman F and Vandesompele J: Aberrant methylation of candidate tumor suppressor genes in neuroblastoma. Cancer Lett 273: 336-346, 2009.

34. Geli J, Kogner P, Lanner F, Natalishvili N, Juhlin C, Kiss N, Clark GJ, Ekstrom TJ, Farnebo F and Larsson C: Assessment of NORE1A as a putative tumor suppressor in human neuroblastoma. Int J Cancer 123: 389-394, 2008.

35. Brodeur GM, Pritchard J, Berthold F, Carlsen NL, Castel V, Castelberry RP, De Bernardi B, Evans AE, Favrot M and Hedborg F: Revisions of the international criteria for neuroblastoma diagnosis, staging, and response to treatment. J Clin Oncol 11: 1466-1477, 1993.

36. Martinsson T, Sjoberg RM, Hedborg F and Kogner P: Deletion of chromosome 1p loci and microsatellite instability in neuroblastomas analyzed with short-tandem repeat polymorphisms. Cancer Res 55: 5681-5686, 1995.
37. Sasaki O, Meguro K, Tohmiya Y, Funato T, Shibahara S and Sasaki T: Altered expression of retinoblastoma protein-interacting zinc finger gene, RIZ, in human leukaemia. Br J Haematol 119: 940-948, 2002.

38. Wang Q, Diskin S, Rappaport E, Attiyeh E, Mosse Y, Shue D, Seiser E, Jagannathan J, Shusterman S, Bansal M, Khazi D, Winter C, Okawa E, Grant G, Cnaan A, Zhao H, Cheung NK, Gerald W, London W, Matthay KK, Brodeur GM, and Maris JM: Integrative genomics identifies distinct molecular classes of neuroblastoma and shows that multiple genes are targeted by regional alterations in DNA copy number. Cancer Res 66: 6050-6062, 2006

39. Caren H, Ejeskar K, Fransson S, Hesson L, Latif F, Sjoberg RM, Krona C and Martinsson T: A cluster of genes located in 1p36 are down-regulated in neuroblastomas with poor prognosis, but not due to $\mathrm{CpG}$ island methylation. Mol Cancer 4: 10, 2005.

40. Caren H, Fransson S, Ejeskar K, Kogner P and Martinsson T: Genetic and epigenetic changes in the common 1p36 deletion in neuroblastoma tumours. Br J Cancer 97: 1416-1424, 2007.

41. Fransson S, Martinsson T and Ejeskar K: Neuroblastoma tumors with favorable and unfavorable outcomes: significant differences in mRNA expression of genes mapped at 1p36.2. Genes Chromosomes Cancer 46: 45-52, 2007.

42. Okawa ER, Gotoh T, Manne J, Igarashi J, Fujita T, Silverman KA, Xhao H, Mosse YP, White PS and Brodeur GM: Expression and sequence analysis of candidates for the 1p36.31 tumor suppressor gene deleted in neuroblastomas. Oncogene 27 : 803-810, 2008

43. Van Noesel MM, van Bezouw S, Voute PA, Herman JG, Pieters R and Versteeg R: Clustering of hypermethylated genes in neuroblastoma. Genes Chromosomes Cancer 38: 226-233, 2003.

44. Herman JG, Graff JR, Myohanen S, Nelkin BD and Baylin SB: Methylation-specific PCR: a novel PCR assay for methylation status of CpG islands. Proc Natl Acad Sci USA 93: 9821-9826, 1996.

45. Kundu $\mathrm{S}$ and Peterson CL: Role of chromatin states in transcriptional memory. Biochim Biophys Acta 1790: 445-455, 2009. 